\title{
Revision adenoidectomy in children: a meta-analysis*
} \author{
Ming-Tzer Lin ${ }^{5,6}$, Kun-Tai Kang ${ }^{1,2}$ \\ ' Department of Otolaryngology, Taipei Hospital, Ministry of Health and Welfare, New Taipei City, Taiwan \\ 2Department of Otolaryngology, National Taiwan University Hospital, Taipei, Taiwan \\ Department of Nursing, Hsin Sheng Junior College of Medical Care and Management, Taoyuan, Taiwan \\ ${ }^{4}$ Department of Otolaryngology, College of Medicine, National Taiwan University \\ Sleep Center, National Taiwan University Hospital, Taipei, Taiwan \\ ${ }^{6}$ Department of Internal Medicine, Hsiao Chung-Cheng Hospital, New Taipei City, Taiwan
}

Chia-Hsuan Lee 1,2,3, Wei-Chung Hsu' ${ }^{2,4,5}$, Jenq-Yuh Ko ${ }^{2,4}$, Te-Huei Yeh ${ }^{2,4}$,

Rhinology 57: 6, 411 - 419, 2019

https://doi.org/10.4193/Rhin19.101

*Received for publication:

February 24, 2019

Accepted: June 27, 2019

\begin{abstract}
Background: To estimate the rate of revision surgery after previous adenoidectomy in children and to compare the rate of revision adenoidectomy in children with different conditions and by using different surgical techniques.

Methodology: The study protocol was registered on PROSPERO (CRD42018107877). Two authors independently searched databases, specifically PubMed, MEDLINE, EMBASE, and the Cochrane Review database. The keywords used were "adenoids," "adenoidectomy," "reoperation," "revision," and "regrowth."The revision rate was pooled using a random-effect model. Subgroup analyses were conducted for children based on different settings, countries, risks of bias, and surgical techniques.
\end{abstract}

Results: A total 16 studies with 95727 children were analyzed (mean age: 4.69 (1.62) years; 60\% boys; sample size: 5983 patients). Five studies had a low risk of bias, 10 studies had a moderate risk of bias, and one study had a high risk of bias. The rate of revision adenoidectomy was $1.9 \%$. Ages at initial surgery and follow-up were not significantly associated with revision surgeries. The revision rate was not significantly different in children receiving surgeries in different settings (single center vs multicenter vs population-based, country (non-United States vs United States, and risk of bias. Moreover, surgical techniques, such as curettage, suction cautery, microdebridement, and coblation did not significantly affect revision rates in children who received adenoidectomy.

Conclusions: Revision surgery was undertaken with a frequency of $1.9 \%$ in children who underwent adenoidectomy. A lack of strong evidence exists to correlate surgical techniques with revision rate in pediatric adenoidectomy.

Key words: adenoidectomy, adenoids, child, reoperation

\section{Introduction}

The adenoid is a lymphoid tissue that lies in the nasopharynx ${ }^{(1)}$. The adenoid plays an essential role in upper airway infections and obstructive sleep disorders ${ }^{(1)}$. Adenoidectomy is usually conducted because of recurrent nasal symptoms ${ }^{(2,3)}$, otitis media with effusion ${ }^{(4,5)}$, and sleep-disordered breathing ${ }^{(6-12)}$. Currently, adenoidectomy is still one of the most common surgical procedures performed in pediatric populations worldwide (1). Adenoids rarely regrow after adenoidectomy ${ }^{(13)}$. However, children with symptoms caused by regrown adenoid tissues may eventually require revision surgeries ${ }^{(14-16)}$. The incidence and risk factors of revision surgeries are of clinical concern ${ }^{(14-17)}$. Nevertheless, a meta-analysis of revision adenoidectomies in children has never been conducted. Moreover, adenoid surgeries can be performed using different surgical techniques, such as curettage, suction diathermy, microdibridement, and coblation ${ }^{(18-23)}$. A meta-analysis by Reed et al. showed the preponderance of electrocautery over curette adenoidectomy in terms of short-term outcomes, such as a decreased intraoperative hemorrhage and operative time ${ }^{(24)}$. However, the effects of surgical techniques on long-term revision surgeries are still under debate.

The aim of this study is to clarify the epidemiology of pediatric 
adenoidectomy. First, the revision rates of children receiving adenoidectomy were estimated. Second, the revision rates were compared in children with different parameters, such as setting, country, and risk of bias. Correlations between age at initial surgery and revision adenoidectomy were explored. In particular, revision rates were evaluated for pediatric adenoidectomy using different surgical techniques.

\section{Methods}

Search strategy

A meta-analysis was conducted according to the PRISMA statement and the recommendations of the Meta-analysis of Observational Studies in Epidemiology group ${ }^{(25)}$. The study protocol was registered in PROSPERO (CRD42018107877) (26). Two authors independently searched databases, including PubMed, MEDLINE, EMBASE, and the Cochrane Review database for articles published until September 2018. Reference sections of the identified articles were searched to yield additional articles. The keywords searched were "adenoids," "adenoidectomy," "reoperation," "revision," and "regrowth." Table 1 lists the keywords used in searching process.

The inclusion criteria were as follows: Patients younger than 18 years receiving adenoidectomy were included. Revision surgery was regarded as the endpoint for evaluation. Therefore, papers included in this meta-analysis contained information on revision surgeries, and papers that failed to report the rate of revision were excluded.

The exclusion criteria were based primarily on the absence of one of the inclusion criteria. Case reports, abstracts, letters to editors, and unpublished studies were excluded. The initial search was conducted by the two key reviewers (CH Lee and MT Lin) independently and was checked by the other two researchers (WC Hsu and KT Kang).

\section{Risk of bias assessment}

A risk-of-bias tool was applied for a systematic review of the prevalence studies ${ }^{(27)}$. The tool comprised 10 items: 1 ) national representativeness, 2) target population representativeness, 3) random selection or census undertaken, 4) minimal nonresponse bias, 5) data collected from patients, 6) acceptable case definition used, 7) valid and reliable study instrument used, 8) same mode of data collection for all patients, 9) length of the shortest prevalence period, and 10) appropriateness of numerator(s) and denominator(s) for the parameter. Items 1-4 were used to assess the external validity (selection and nonresponse bias) and items 5-10 were used to assess the internal validity of the study (measurement and analysis bias). All these items were rated "high" or "low." Item 11, the summary assessment, evaluated the overall risk of study bias and was based on the author's subjective judgment of the preceding 10 items rated as low-, moderate-, or high-risk. The toolset was used to

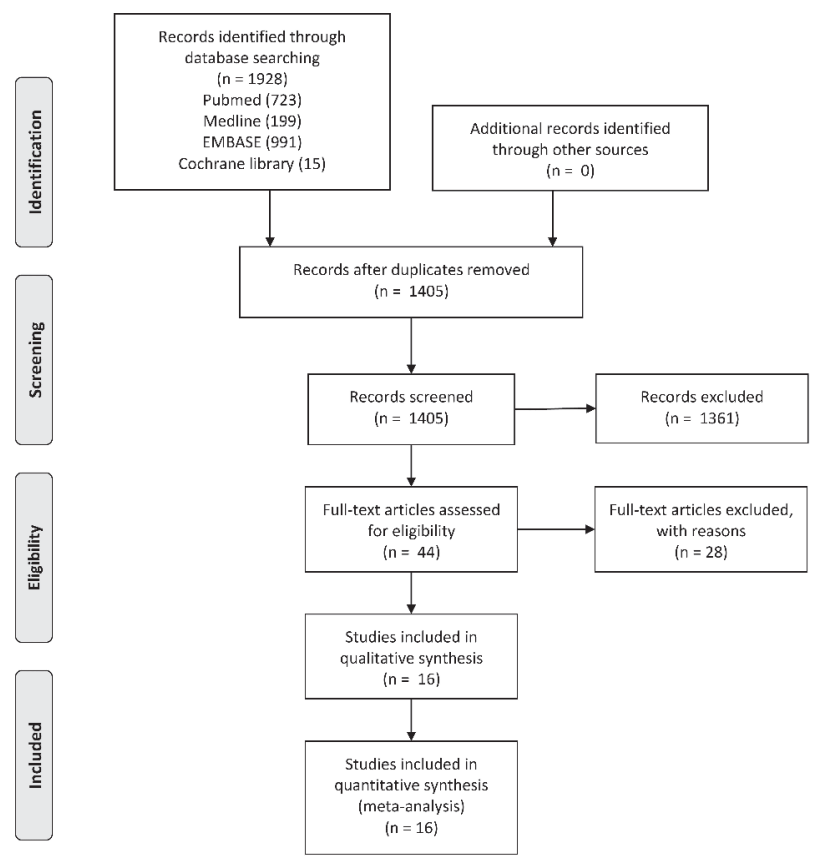

Figure 1. Flow diagram of literature search.

assess the risk of bias in each article separately by two authors (Lin MT and Kang KT), and disagreements were resolved by consensus.

\section{Statistical analysis}

Data were extracted using Microsoft Excel and analyzed using Comprehensive Meta-analysis Version 2 (Biostat Inc., Englewood, NJ, USA, 2005). The incidence (event rate) of revision adenoidectomy was pooled using a random-effect model. Statistical heterogeneity among the studies was assessed using $\mathrm{I}^{2}$ statistics that measured the proportion of overall variation attributable to between-study heterogeneity ${ }^{(28)}$. An $I^{2}$ statistic greater than $50 \%$ indicated moderate heterogeneity, whereas those greater than $75 \%$ indicated high heterogeneity. The correlation between continuous factors (i.e., age at initial surgery, publication year, follow-up year, and sample size) and revision rates was explored using a mixed-effect metaregression analysis. The revision rates were compared among studies in different subgroups (i.e., setting, country, risk of bias, and surgical technique) by mixed-effect models. Publication bias was assessed using the funnel plot accompanied by the Egger's intercept test. A two-side $P$ value of less than 0.05 was considered statistically significant.

\section{Results}

Literature search

Figure 1 demonstrates the literature search process. Supplement Table 1 lists searching process in the database. The initial web-based search yielded 1405 studies and abstracts. Studies that were unpublished, contained no Apnea-Hypopnea Index data, or did not include a pediatric population were excluded. In 
Table 1. MeSH terms and keywords used in searching process.

(1) "adenoids"[MeSH] OR "adenoidectomy"[MeSH]

(2) "Reoperation"[MeSH] OR "revision" OR "re-growth" OR "epidemiology"[MeSH]

(1) AND (2)

Data source: PubMed, MEDLINE, EMBASE, and Cochrane.

total, 44 potentially pertinent studies were identified. Finally, 16 studies were included in the quantitative analyses (Table 2) ${ }^{(29-44)}$.

\section{Basic characteristics}

Table 2 shows the basic characteristics of the included studies. A total of 16 studies with 95727 children were analyzed. The mean age was 4.69 years (standard deviation $=1.62$ years) and boys comprised $60 \%$ of all the children. The mean sample size was 5983 patients. Eight studies were conducted in the United States $(29,30,33,35,36,38,43,44)$. The others were conducted in the United Kingdom ${ }^{(31,32)}$, Egypt ${ }^{(34)}$, Canada ${ }^{(37)}$, Germany ${ }^{(39)}$, South Korea ${ }^{(40)}$, New Zealand ${ }^{(41)}$, and Taiwan ${ }^{(42)}$. Most studies recruited their patients in a single hospital ${ }^{(29-34,36-38,40-41,44)}$ or multicenter setting ${ }^{(35,43)}$. Two studies identified their patients through a population-based setting ${ }^{(39,42)}$. Four surgical techniques were used for pediatric adenoidectomy: curettage, suction cautery, microdebridement, and coblation. Table 2 summarizes the basic data, risk factors, and main findings of the included studies.

\section{Risk of bias}

Supplement Table 2 lists the risk of bias results of the included studies. Five studies had a low risk of bias, 10 studies had a moderate risk of bias, and one study had a high risk of bias. Revision rate following pediatric adenoidectomy According to a random-effect model, the pooled event rate of revision surgery was $1.9 \%(95 \% \mathrm{Cl}, 1.3 \%-2.9 \%)$ in children who underwent adenoidectomies, with high heterogeneity $\left(\mathrm{I}^{2}=\right.$ 98.3\%) (Figure 2).

\section{Metaregression for factors associated with revision rate}

A metaregression model was used to analyze the correlations between continuous factors and revision rates. Age at initial surgery was not significantly correlated with the revision rate in pediatric adenoidectomy (regression coefficient [B], -0.07 ; $95 \% \mathrm{Cl},-0.43$ to 0.29 ). Year of publication was not significantly correlated with the revision rate in pediatric adenoidectomy $\left(B_{1}\right.$ $-0.007 ; 95 \% \mathrm{Cl},-0.10$ to 0.08 ). Follow-up period was also not significantly correlated with the revision rate in pediatric adenoidectomy ( $\mathrm{B},-0.05 ; 95 \% \mathrm{Cl},-0.13$ to 0.03 ). However, sample size was slight inversely correlated with the revision rate in pediatric adenoidectomies $(\mathrm{B},-0.06 ; 95 \% \mathrm{Cl},-0.12$ to -0.003$)$, indicating that studies with larger sample sizes may have a lower revision rate.

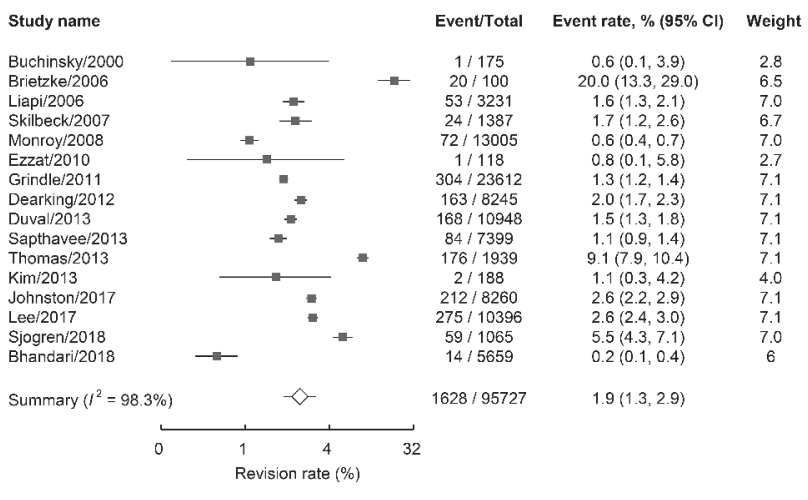

Figure 2. Overall rate of revision adenoidectomy in children.

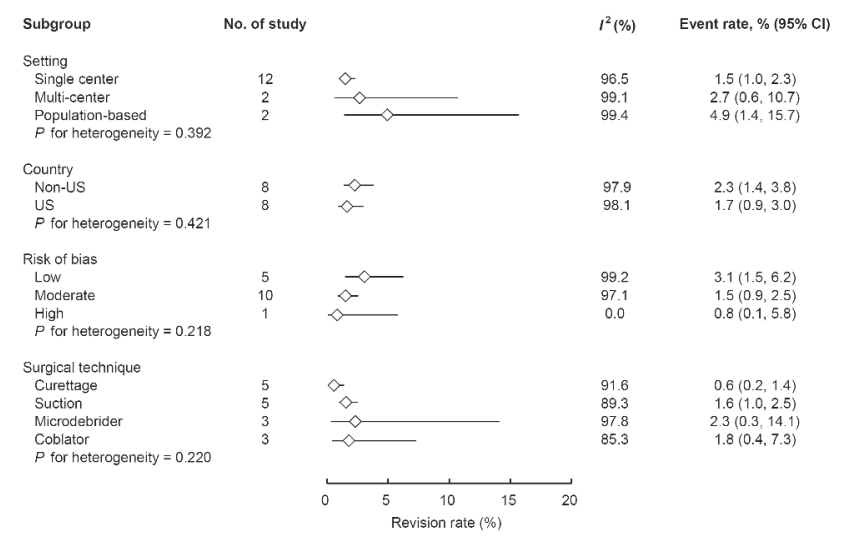

Figure 3. Subgroups analysis of rate of revision adenoidectomy.

\section{Subgroup analysis}

For children who underwent adenoidectomies, subgroup analysis was performed to compare the revision rate among different settings, countries, risks of bias, and surgical techniques (Figure 3). Revision rate did not significantly differ among the different settings (single center vs multicenter vs population; $1.5 \%$ vs $2.7 \%$ vs $4.9 \%, P=0.39$ ), countries (non-United States vs United States; $2.3 \%$ vs $1.7 \%, \mathrm{P}=0.42$ ), and risks of bias (low vs moderate vs high; $3.1 \%$ vs $1.5 \%$ vs $0.8 \%, \mathrm{P}=0.22$ ). Moreover, the revision rate was not significantly different among different techniques, such as curettage, suction cautery, microdebridement, or coblation $(0.6 \%$ vs $1.6 \%$ vs $2.3 \%$ vs $1.8 \% ; P=0.22)$.

\section{Publication bias}

Figure 4 shows the funnel plot for standard error by incidence of revision surgeries. The plot is generally symmetrical, suggesting no obvious publication bias. The Egger's test result was also not significant, indicating no apparent publication bias $(P=0.81)$.

\section{Discussion}

This study was the first to conduct a meta-analysis elaborating on the epidemiology of revision adenoidectomy in a pediatric population. One of the main purposes of this study was to clarify the revision rate of pediatric adenoidectomy, and our results re- 
Table 2. Demographics of included studies.

\begin{tabular}{|c|c|c|c|c|c|c|c|c|c|c|c|}
\hline $\begin{array}{l}\text { First } \\
\text { author } \\
\text { Year }\end{array}$ & $\underset{\text { try }}{\text { Coun- }}$ & $\mathbf{N}$ & $\begin{array}{l}\text { Risk of } \\
\text { bias }\end{array}$ & $\begin{array}{l}\text { Mean } \\
\text { age }\end{array}$ & $\begin{array}{c}\text { Male } \\
\%\end{array}$ & Design & $\begin{array}{l}\text { Surgical } \\
\text { technique }\end{array}$ & Revision rate & $\begin{array}{l}\text { Mean } \\
\text { time be- } \\
\text { tween } \\
\text { primary } \\
\text { and } \\
\text { revision } \\
\text { surgery }\end{array}$ & $\begin{array}{l}\text { Risk factor for } \\
\text { revision }\end{array}$ & $\begin{array}{l}\text { Mean } \\
\text { follow } \\
\text { up } \\
\text { period }\end{array}$ \\
\hline $\begin{array}{l}\text { Buchinsky } \\
2000^{29}\end{array}$ & USA & 175 & Moderate & $5.9 y$ & NR & $\begin{array}{l}\text { Single } \\
\text { hospital }\end{array}$ & Curettage & $0.57 \%$ & NR & NR & 3.3 years \\
\hline $\begin{array}{l}\text { Brietzke } \\
2006^{30}\end{array}$ & USA & 100 & Moderate & $3.9 y$ & $73 \%$ & $\begin{array}{l}\text { Single } \\
\text { hospital }\end{array}$ & $\begin{array}{l}\text { Curettage or } \\
\text { cautery }\end{array}$ & $\begin{array}{l}\text { Non-obstruc- } \\
\text { tive symp- } \\
\text { tom = } 12 \% \text {; } \\
\text { Obstructive } \\
\text { symptom = } \\
27 \%\end{array}$ & $2.5 y$ & $\begin{array}{l}\text { Preoperative } \\
\text { obstructive } \\
\text { symptoms }\end{array}$ & $\begin{array}{l}3.46 \\
\text { years }\end{array}$ \\
\hline $\begin{array}{l}\text { Liapi } \\
2006^{31}\end{array}$ & UK & 3231 & Moderate & $5.2 y$ & $49 \%$ & $\begin{array}{l}\text { Single } \\
\text { hospital }\end{array}$ & Curettage & $1.6 \%$ & $3.5 y$ & NR & NR \\
\hline $\begin{array}{l}\text { Skilbeck } \\
2007^{32}\end{array}$ & UK & 1387 & Moderate & NR & $59 \%$ & $\begin{array}{l}\text { Single } \\
\text { hospital }\end{array}$ & $\begin{array}{l}\text { Suction coa- } \\
\text { gulation }\end{array}$ & $1.7 \%$ & $\begin{array}{l}21 \\
\text { months }\end{array}$ & NR & $\begin{array}{l}6 \\
\text { months }\end{array}$ \\
\hline $\begin{array}{l}\text { Monroy } \\
2008^{33}\end{array}$ & USA & 13005 & Moderate & $3.7 \mathrm{y}$ & $53 \%$ & $\begin{array}{l}\text { Single } \\
\text { hospital }\end{array}$ & Curettage & $0.55 \%$ & $4.3 y$ & Acid reflux & 11 years \\
\hline $\begin{array}{l}\text { Ezzat } \\
2010^{34}\end{array}$ & Egypt & 118 & High & $N R$ & NR & $\begin{array}{l}\text { Single } \\
\text { hospital }\end{array}$ & Curettage & $0.85 \%$ & NR & $\begin{array}{l}\text { Non-examined } \\
\text { group }\end{array}$ & 2 years \\
\hline $\begin{array}{l}\text { Grindle } \\
2011^{35}\end{array}$ & USA & 23612 & Low & $2.8 y$ & NR & $\begin{array}{l}\text { Multistate } \\
\text { system }\end{array}$ & $\begin{array}{l}\text { Curettage, } \\
\text { electrocaute- } \\
\text { ry, micrdebri- } \\
\text { der, coblation }\end{array}$ & $1.29 \%$ & $1.8 y$ & NR & 5 years \\
\hline $\begin{array}{l}\text { Dearking } \\
2012^{36}\end{array}$ & USA & 8245 & Moderate & $6.7 y$ & $54 \%$ & $\begin{array}{l}\text { Single } \\
\text { hospital }\end{array}$ & $\begin{array}{l}\text { Curettage, } \\
\text { electrocaute- } \\
\text { ry, micrdebri- } \\
\text { der, coblation }\end{array}$ & $1.98 \%$ & NR & $\begin{array}{l}\text { Young age, } \\
\text { indication, acid } \\
\text { reflux; Surgical } \\
\text { technique is not a } \\
\text { risk factor }\end{array}$ & 10 years \\
\hline $\begin{array}{l}\text { Duval } \\
2013^{37}\end{array}$ & $\begin{array}{l}\text { Ca- } \\
\text { nada }\end{array}$ & 10948 & Low & $5.9 y$ & $58 \%$ & $\begin{array}{l}\text { Single } \\
\text { hospital }\end{array}$ & $\begin{array}{l}\text { Curettage, } \\
\text { electrocau- } \\
\text { tery }\end{array}$ & $1.53 \%$ & $\begin{array}{l}40 \\
\text { months }\end{array}$ & $\begin{array}{l}\text { Age }<5 \text { y, adenoi- } \\
\text { dectomy without } \\
\text { Tonsillectomy; } \\
\text { Curettage tech- } \\
\text { nique }\end{array}$ & 20 years \\
\hline $\begin{array}{l}\text { Sapthavee } \\
2013^{38}\end{array}$ & USA & 7399 & Moderate & $3.2 y$ & $64 \%$ & $\begin{array}{l}\text { Single } \\
\text { hospital }\end{array}$ & $\begin{array}{l}\text { Microdebri- } \\
\text { dervs. suction } \\
\text { coagulation }\end{array}$ & $1.14 \%$ & 2.1 year & $\begin{array}{l}\text { No difference } \\
\text { between surgical } \\
\text { technique }\end{array}$ & 4.5 years \\
\hline $\begin{array}{l}\text { Thomas } \\
2013^{39}\end{array}$ & $\begin{array}{l}\text { Ger- } \\
\text { many }\end{array}$ & 1939 & Low & $4 y$ & $57 \%$ & $\begin{array}{l}\text { Populati- } \\
\text { on-based }\end{array}$ & NR & $9.08 \%$ & NR & Young age & 1 year \\
\hline $\begin{array}{l}\text { Kim } \\
2013^{40}\end{array}$ & $\begin{array}{l}\text { South } \\
\text { Korea }\end{array}$ & 188 & Moderate & $5.8 y$ & $44 \%$ & $\begin{array}{l}\text { Single } \\
\text { hospital }\end{array}$ & Coblator & $1.06 \%$ & NR & NR & 1 year \\
\hline $\begin{array}{l}\text { Johnston } \\
2017^{41}\end{array}$ & $\begin{array}{l}\text { New } \\
\text { Ze- } \\
\text { aland }\end{array}$ & 8260 & Moderate & $5.7 y$ & $52 \%$ & $\begin{array}{l}\text { Single } \\
\text { hospital }\end{array}$ & $\begin{array}{l}\text { Suction } \\
\text { monopolar } \\
\text { diathermy }\end{array}$ & $2.57 \%$ & NR & $\begin{array}{l}\text { Female, old age, } \\
\text { previous antibi- } \\
\text { otic course, indi- } \\
\text { cation, asthma, } \\
\text { allergic rhinitis, } \\
\text { acid reflux }\end{array}$ & 16 years \\
\hline $\begin{array}{l}\text { Lee } \\
2017^{42}\end{array}$ & $\begin{array}{l}\text { Tai- } \\
\text { wan }\end{array}$ & 10396 & Low & $7.3 y$ & $66 \%$ & $\begin{array}{l}\text { Populati- } \\
\text { on-based }\end{array}$ & NR & $2.6 \%$ & $2.97 y$ & $\begin{array}{l}\text { Young age, male, } \\
\text { concurrent pro- } \\
\text { cedure }\end{array}$ & 8.7 years \\
\hline $\begin{array}{l}\text { Sjogren } \\
2018^{43}\end{array}$ & USA & 1065 & Low & $4.5 y$ & $54 \%$ & $\begin{array}{l}\text { Multi- } \\
\text { hospital } \\
\text { Network }\end{array}$ & $\begin{array}{l}\text { Electrocau- } \\
\text { tery vs. micro- } \\
\text { debrider vs. } \\
\text { coblator }\end{array}$ & $\begin{array}{l}\text { Overall = 5.5\%; } \\
\text { Electrocau- } \\
\text { tery= } 2.7 \% \text {; } \\
\text { microdebrider } \\
=9.7 \% ; \text { Cobla- } \\
\text { tor }=5.3 \%\end{array}$ & $\begin{array}{l}695 \\
\text { days }\end{array}$ & $\begin{array}{l}\text { Adenoidectomy } \\
\text { performed with } \\
\text { microdebrider }\end{array}$ & 7 years \\
\hline
\end{tabular}




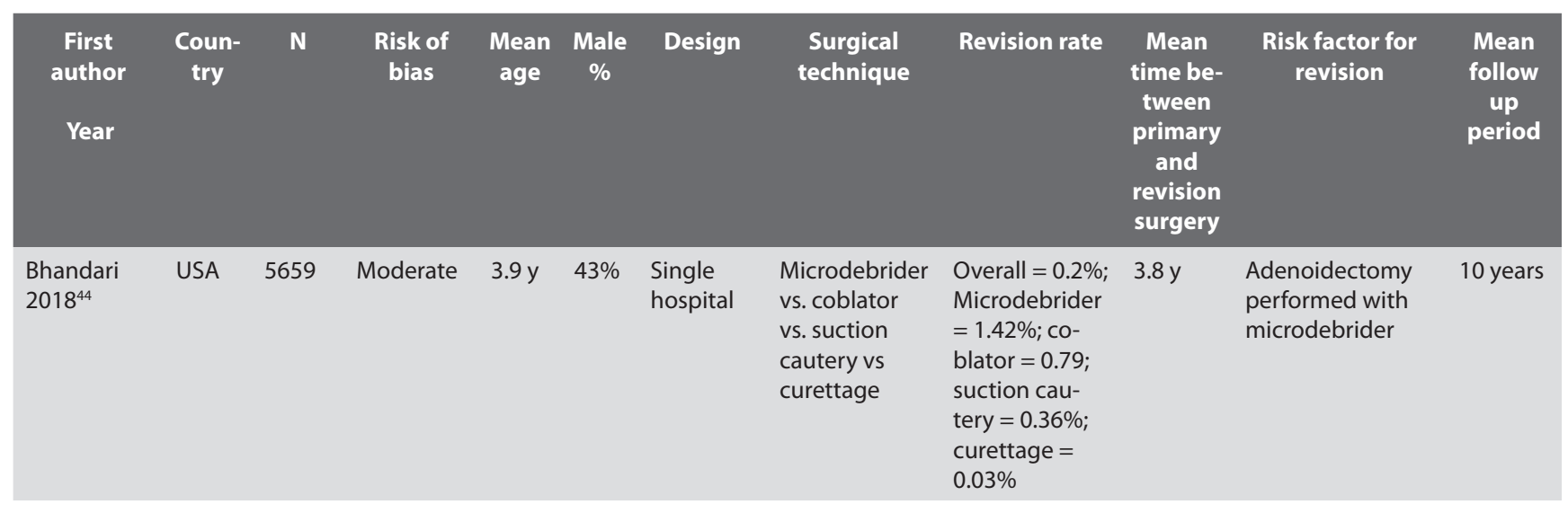

Note: NR = not reported.

vealed that revision surgery was performed with a frequency of $1.9 \%$ in children who underwent adenoidectomy. Another main purpose of this study was to identify risk factors associated with revision surgeries. We systematically reviewed the pertinent literature and conducted a meta-analysis. However, there is a lack of consensus regarding factors associated with revision surgeries. Moreover, several modern techniques (i.e., suction cautery, microdebridement, and coblation) have been introduced for use in adenoid surgeries. Clinicians are particularly interested in whether new surgical techniques are associated with a change in revision rate. Compared with the revision rate performed using the traditional technique (i.e., curettage), revision rates were not significantly altered when surgery was performed used modern surgical techniques. Therefore, adenoidectomies can be performed using traditional or modern surgical techniques depending on surgeon training and preference, and each technique produces a similar outcome in revision rate.

In this meta-analysis, the revision rate was $1.9 \%$ for pediatric adenoidectomy ${ }^{(29-44)}$. In the current study, the overall revision rate ranged from $0.2 \%$ to $9.08 \%$ (Table 2 ). Children were recruited either from a single hospital, multiple centers, or the entire population. Among these studies, only two had a populationbased setting, and the revision rates were $9.08 \%$ and $2.6 \%$ in these cases ${ }^{(39,42)}$. The overall revision rate was not significantly different in the population-based study (4.9\%) as compared with multicenter (2.7\%) and single hospital studies (1.5\%). The overall revision was also similar in the United States (1.7\%) and outside the United States (2.3\%), implying that revision surgery rarely occurred globally.

From a clinical perspective, identifying factors that contribute to adenoid regrowth is imperative and facilitates the development of a protocol to reduce the requirement for revision surgery. Several risk factors have been proposed for revision surgery after pediatric adenoidectomy ${ }^{(29-44)}$. However, there is still a lack of consistent findings between each study. Brietzke et al. found that children with obstructive symptoms before surgery are more likely to undergo revision surgery ${ }^{(30)}$. Ezzat et al. described the use of endoscopic examination to reduce adenoid recurrence rates ${ }^{(34)}$. Monroy et al. ${ }^{(33)}$ and Dearking et al. ${ }^{\left({ }^{(3)}\right)}$ have demonstrated that children with acid reflux disease are at risk of adenoid recurrence and the requirement for revision surgery. Johnston et al. ${ }^{(41)}$ found that the female sex is associated with revision surgery in a hospital-based study, whereas a population-based study by Lee et al. ${ }^{(42)}$ described revision surgery as being more likely to occur in male patients. Association between ages and revision adenoidectomies have also been studied. Based on the normal growth patterns of adenoids in children, the adenoid size increased during the first 7-8 years of life and then decreased gradually ${ }^{(45)}$. Therefore, ages at initial surgery have been considered to affect revision surgery. Young ages at initial surgery have been reported by Dearking et al. ${ }^{(36)}$, Duval et al. ${ }^{(37)}$, Thomas et al. ${ }^{(39)}$, and Lee et al. ${ }^{(42)}$. However, Johnston et al. ${ }^{(41)}$ described older age as being associated with revision surgery ${ }^{(41)}$. Metaregression analysis in this study showed age as being not significantly associated with revision rate. Therefore, the timing of surgery should still be determined according to a child's condition and the physician's clinical judgments.

Conventionally, adenoid tissues are removed by cold dissection using adenotome curettes. In the 1980s, however, the addition of suction electrocautery to control bleeding after curettage became popular ${ }^{(46)}$. Many techniques for surgical removal of the adenoids have since been described ${ }^{(18-23)}$. The most commonly cited advantage of this technique over curettage is the ability to precisely remove obstructing choanal adenoid tissue using compact surgical devices ${ }^{(24)}$. In 2009, a meta-analysis by Reed et al. compared outcomes of suction cautery adenoidectomies to those using conventional curettage techniques ${ }^{(24)}$. Reed et al. found that the use of electrocautery for adenoidectomies, as compared with those using curettage, were associated with a decrease in intraoperative bleeding and operative time (24). However, outcomes of other techniques (i.e., microdebridement and coblation) were not examined. Moreover, the impact of 


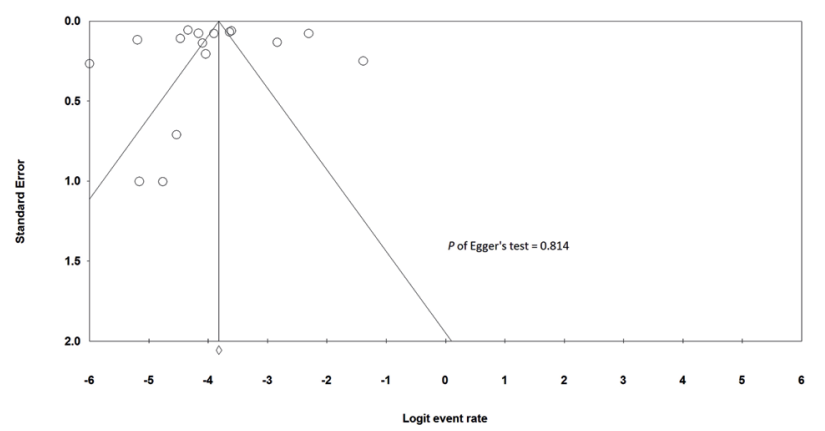

Figure 4. Funnel plot of standard error by difference in means of the revision rate. The symmetry of this plot indicates no apparent publication bias.

surgical techniques on revision surgeries is not well clarified. Dearking et al. ${ }^{\left({ }^{36}\right)}$ and Sapthavee et al. ${ }^{(30)}$ have observed no significant correlation between surgical techniques and revision rates. By contrast, recent studies by Sjogren et al. ${ }^{(43)}$ and Bhandari et al. ${ }^{(44)}$ have reported a higher revision rate from using microdebridement compared with other techniques. In our meta-analysis, revision rates in children using curettage, suction cautery, microdebridement, and coblation were $0.6 \%, 1.6 \%$, $2.3 \%$, and $1.8 \%$, respectively, and were not significantly different between each other. These findings suggest a low revision rate when pediatric adenoidectomies are performed using a wide variety of surgical techniques.

This study has certain limitations. First, this meta-analysis stems from a heterogeneity of data from various sources, and disparities in the settings of each study were noted when interpreting the data. Second, most studies are case series in design. A randomized controlled trial is highly desired to compare beneficial effects and complications in different surgical techniques for adenoidectomy. Third, there is a lack of population-based studies addressing the effects of surgical techniques on pediatric adenoidectomy ${ }^{(47-51)}$. Studies included in this meta-analysis were mostly hospital-based studies. Therefore, future studies should investigate correlations between surgical techniques and outcomes in a population-based setting.

\section{Conclusion}

The overall revision rate of adenoidectomy was approximately $1 \%-2 \%$ in children. Revision rates remained low despite children receiving surgeries in different settings and countries. Furthermore, based on the literature, surgical techniques, such as curettage, suction cautery, microdebridement, and coblation, do not significantly affect revision rates.

\section{Acknowledgement}

Kun-Tai Kang and Ming-Tzer Lin both equally participated in this study's design and coordination and are acknowledged as cocorresponding authors. All authors read and approved the final manuscript. The authors would like to thank the anonymous reviewers and the editors for their comments.

\section{Author contribution}

Chia-Hsuan Lee, study concept and design, acquisition of data, analysis and interpretation of data, drafting of the manuscript, statistical analysis, critical revision of the manuscript for important intellectual content; Wei-Chung Hsu, acquisition of data, analysis and interpretation of data, statistical analysis, revising manuscript critically for important intellectual content; JenqYuh Ko, acquisition of data, critical revision of the manuscript for important intellectual content; Te-Huei Yeh, acquisition of data, critical revision of the manuscript for important intellectual content; Ming-Tzer Lin, study concept and design, acquisition of data, analysis and interpretation of data, drafting of the manuscript, critical revision of the manuscript for important intellectual content; Kun-Tai Kang, takes responsibility for the content of the paper, study concept and design, acquisition of data, analysis and interpretation of data, drafting of the manuscript, critical revision of the manuscript for important intellectual content.

\section{Conflict of interest}

The authors declare no conflicts of interest.

\section{References}

1. Ingram DG, Friedman NR. Toward adenotonsillectomy in children: a review for the general pediatrician. JAMA Pediatr. 2015;169(12):1155-1161.

2. van den Aardweg MT, Schilder AG, Herkert E, Boonacker CW, Rovers MM Adenoidectomy for recurrent or chronic nasal symptoms in children. Cochrane Database Syst Rev. 2010;(1):CD008282.

3. Brietzke SE, Brigger MT. Adenoidectomy outcomes in pediatric rhinosinusitis: a meta-analysis. Int J Pediatr Otorhinolaryngol. 2008;72(10):1541-1545.

4. Mikals SJ, Brigger MT. Adenoidectomy as an adjuvant to primary tympanostomy tube placement: a systematic review and metaanalysis. JAMA Otolaryngol Head Neck Surg. 2014;140(2):95-101.

5. van den Aardweg MT, Schilder AG, Herkert E, Boonacker CW, Rovers MM. Adenoidectomy for otitis media in children. Cochrane Database Syst Rev. 2010;(1):CD007810.

6. Reckley LK, Song SA, Chang ET, Cable BB, Certal V, Camacho M. Adenoidectomy can improve obstructive sleep apnoea in young children: systematic review and meta-analysis. J Laryngol Otol. 2016;130(11):990-994.

7. Lee $\mathrm{CH}$, Hsu WC, Chang WH, Lin MT, Kang KT. Polysomnographic findings after adenotonsillectomy for obstructive sleep apnoea in obese and non-obese children: a systematic review and meta-analysis. Clin Otolaryngol. 2016;41(5):498-510.

8. Kang KT, Chang IS, Tseng CC, et al. Impacts of disease severity on postoperative complications in children with sleepdisordered breathing. Laryngoscope. 2017;127(11):2646-2652.

9. Chang IS, Kang KT, Tseng CC, et al. Revisits after adenotonsillectomy in children with sleep-disordered breathing: a retrospective single-institution study. Clin Otolaryngol. 2018;43(1):39-46.

10. Lee $\mathrm{CH}$, Kang KT, Chiu SN, et al. Association of adenotonsillectomy with blood pressure among hypertensive and nonhyper- 
tensive children with obstructive sleep apnea. JAMA Otolaryngol Head Neck Surg. 2018;144(4):300-307.

11. Hsu WC, Kang KT, Chiu SN, Weng WC, Lee PL, Lin CY. 24-hour ambulatory blood pressure after adenotonsillectomy in childhood sleep apnea: a prospective 3-month followup study. J Pediatr. 2018;199:112-117.

12. Kang KT, Chiu SN, Lin CY, Weng WC, Lee PL, Hsu WC. Effect of adenotonsillectomy on 24-hour ambulatory blood pressure in children with obstructive sleep apnea: prospective six-month follow-up study. Otolaryngol Head Neck Surg. 2019;160(5):911-921.

13. Saxby AJ, Chappel CA. Residual adenoid tissue post-curettage: role of nasopharyngoscopy in adenoidectomy. ANZ J Surg. 2009;79(11):809-811.

14. Lesinskas $E$, Drigotas $M$. The incidence of adenoidal regrowth after adenoidectomy and its effect on persistent nasal symptoms. Eur Arch Otorhinolaryngol. 2009;266(4):469473.

15. Joshua B, Bahar G, Sulkes J, Shpitzer T, Raveh E. Adenoidectomy: long-term follow-up. Otolaryngol Head Neck Surg. 2006;135(4):576-580.

16. Kim SY, Lee WH, Rhee CS, Lee CH, Kim JW Regrowth of the adenoids after coblation adenoidectomy: cephalometric analysis Laryngoscope. 2013;123(10):2567-2572.

17. Emerick KS, Cunningham MJ. Tuba tonsil hypertrophy: a cause of recurrent symptoms after adenoidectomy. Arch Otolaryngol Head Neck Surg. 2006;132(2):153-156.

18. Clemens J, McMurray JS, Willging JP. Electrocautery versus curette adenoidectomy: comparison of postoperative results. Int J Pediatr Otorhinolaryngol. 1998;43(2):115122.

19. Walker P. Pediatric adenoidectomy under vision using suction-diathermy ablation. Laryngoscope. 2001;111(12):2173-2177.

20. Elluru RG, Johnson L, Myer CM 3rd. Electrocautery adenoidectomy compared with curettage and power-assisted methods. Laryngoscope. 2002;112:23-25.

21. Jonas NE, Sayed R, Prescott CA. Prospective randomized, single-blind, controlled study to compare two methods of performing adenoidectomy. Int J Pediatr Otorhinolaryngol. 2007;71(10):1555-1562.

22. Duarte VM, Liu YF, Shapiro NL. Coblation total tonsillectomy and adenoidectomy versus coblation partial intracapsular tonsillectomy and adenoidectomy in children. Laryngoscope. 2014;124(8):1959-1964.

23. Mularczyk C, Walner DL, Hamming KK Coblation versus microdebrider in pediatric adenoidectomy. Int J Pediatr Otorhinolaryngol. 2018;104:29-31

24. Reed J, Sridhara S, Brietzke SE. Electrocautery adenoidectomy outcomes: a meta-analysis. Otolaryngol Head Neck Surg.
2009;140(2):148-153.

25. Moher D, Liberati A, Tetzlaff J, Altman DG. Preferred reporting items for systematic reviews and meta-analyses: the PRISMA statement. J Clin Epidemiol. 2009;62(10):1006-1012.

26. PROSPERO International Prospective Register of Systematic Reviews. Revision adenoidectomy in children: a systematic review and meta-analysis. PROSPERO 2018 CRD42018107877 Available from: http:// www.crd.york.ac.uk/PROSPERO/display_ record.php?|D=CRD42018107877. Accessed February 24, 2019.

27. Hoy D, Brooks P, Woolf A, et al. Assessing risk of bias in prevalence studies: modification of an existing tool and evidence of interrater agreement. J Clin Epidemiol. 2012;65(9):934-939.

28. Higgins JP, Thompson SG, Deeks JJ, Altman DG. Measuring inconsistency in meta-analyses. BMJ 2003;327:557-560.

29. Buchinsky FJ, Lowry MA, Isaacson G. Do adenoids regrow after excision? Otolaryngol Head Neck Surg. 2000;123(5):576-581.

30. Brietzke SE, Kenna M, Katz ES, Mitchell E, Roberson D. Pediatric adenoidectomy: what is the effect of obstructive symptoms on the likelihood of future surgery? Int J Pediatr Otorhinolaryngol. 2006;70(8):14671472.

31. Liapi A, Dhanasekar G, Turner NO. Role of revision adenoidectomy in paediatric otolaryngological practice. J Laryngol Otol. 2006;120(3):219-221.

32. Skilbeck CJ, Tweedie DJ, Lloyd-Thomas AR, Albert DM. Suction diathermy for adenoidectomy: complications and risk of recurrence. Int J Pediatr Otorhinolaryngol. 2007;71(6):917-920.

33. Monroy A, Behar P, Brodsky L. Revision adenoidectomy-a retrospective study. Int J Pediatr Otorhinolaryngol. 2008;72(5):565570

34. Ezzat WF. Role of endoscopic nasal examination in reduction of nasopharyngeal adenoid recurrence rates. Int J Pediatr Otorhinolaryngol. 2010;74(4):404-406.

35. Grindle CR, Murray RC, Chennupati SK, Barth PC, Reilly JS. Incidence of revision adenoidectomy in children. Laryngoscope. 2011;121(10):2128-2130.

36. Dearking AC, Lahr BD, Kuchena A, Orvidas LJ. Factors associated with revision adenoidectomy. Otolaryngol Head Neck Surg. 2012;146(6):984-990.

37. Duval M, Chung JC, Vaccani JP. A casecontrol study of repeated adenoidectomy in children. JAMA Otolaryngol Head Neck Surg. 2013;139(1):32-36.

38. Sapthavee A, Bhushan B, Penn E, Billings KR A comparison of revision adenoidectomy rates based on techniques. Otolaryngol Head Neck Surg. 2013;148(5):841-846.

39. Thomas K, Boeger D, Buentzel J, et al.
Pediatric adenoidectomy: a populationbased regional study on epidemiology and outcome. Int J Pediatr Otorhinolaryngol. 2013;77(10):1716-1720.

40. Kim SY, Lee WH, Rhee CS, Lee CH, Kim JW. Regrowth of the adenoids after coblation adenoidectomy: cephalometric analysis. Laryngoscope. 2013;123(10):2567-2572.

41. Johnston J, Mahadevan M, Douglas RG. Incidence and factors associated with revision adenoidectomy: a retrospective study. Int J Pediatr Otorhinolaryngol. 2017;103:125-128

42. Lee $\mathrm{CH}$, Chang WH, Ko JY, Yeh TH, Hsu WC, Kang KT. Revision adenoidectomy in children: a population-based cohort study in Taiwan. Eur Arch Otorhinolaryngol. 2017;274(10):3627-3635.

43. Sjogren PP, Thomas AJ, Hunter BN Butterfield J, Gale C, Meier JD. Comparison of pediatric adenoidectomy techniques. Laryngoscope. 2018;128(3):745-749.

44. Bhandari N, Don DM, Koempel JA. The incidence of revision adenoidectomy: A comparison of four surgical techniques over a 10-year period. Ear Nose Throat J. 2018;97(6):E5-E9.

45. Papaioannou G, Kambas I, Tsaoussoglou M, Panaghiotopoulou-Gartagani P, Chrousos G, Kaditis AG. Age-dependent changes in the size of adenotonsillar tissue in childhood: implications for sleep-disordered breathing. J Pediatr. 2013;162(2):269-274.

46. Kwok P, Hawke M. The use of suction cautery in adenoidectomy. J Otolaryngol 1987; 16:49-50

47. Lee $\mathrm{CH}$, Hsu WC, Ko JY, Yeh TH, Chang WH, Kang KT. Epidemiology and trend of pediatric adenoidectomy: a population-based study in Taiwan from 1997 to 2012. Acta Otolaryngol. 2017;137(12):1265-1270.

48. Lin DL, Wu CS, Tang CH, Kuo TY, Tu TY. The safety and risk factors of revision adenoidectomy in children and adolescents: A nationwide retrospective populationbased cohort study. Auris Nasus Larynx. 2018;45(6):1191-1198.

49. Hsueh WY, Hsu WC, Ko JY, Yeh TH, Lee CH, Kang KT. Population-based survey of inpatient pediatric tonsillectomy and postoperative hemorrhage in Taiwan, 1997-2012. Int J Pediatr Otorhinolaryngol. 2018;108:55-62.

50. Hsueh WY, Hsu WC, Ko JY, Yeh TH, Lee CH, Kang KT. Postoperative hemorrhage following tonsillectomy in adults: analysis of population-based inpatient cohort in Taiwan. Auris Nasus Larynx. 2018 Nov 1. pii: S0385-8146(18)30569-8. doi: 10.1016/j. anl.2018.10.008. [Epub ahead of print]

51. Hsu YS, Hsu WC, Ko JY, Yeh TH, Lee $\mathrm{CH}$ Kang KT. Readmission after adult uvulopalatopharyngoplasty: a population-based inpatient cohort study in Taiwan. Otolaryngol Head Neck Surg. 2019;160(3):559-566. 


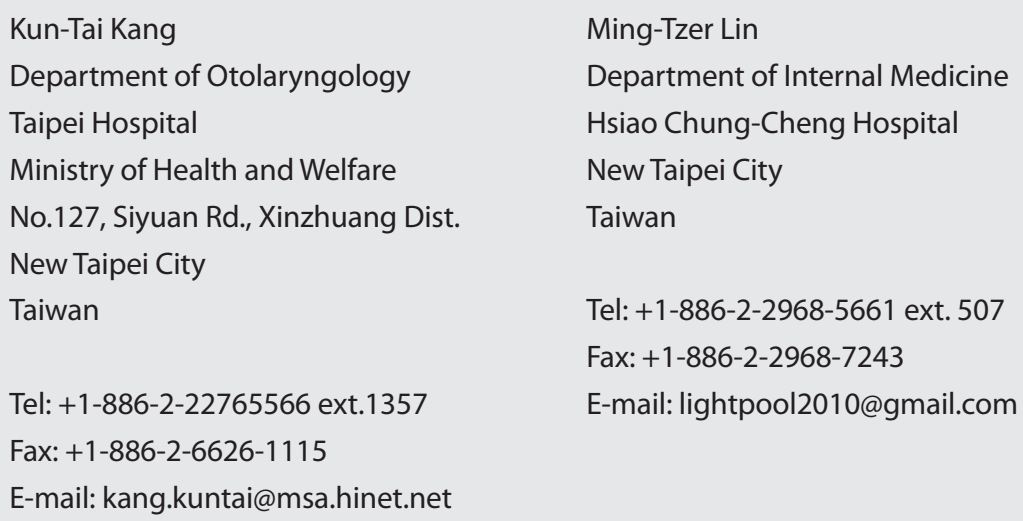

\section{Ming-Tzer Lin}

Department of Internal Medicine

Hsiao Chung-Cheng Hospital

New Taipei City

Taiwan

Tel: +1-886-2-2968-5661 ext. 507

Fax: +1-886-2-2968-7243

E-mail: lightpool2010@gmail.com

Supplement Table 1. Searching process in database.

\section{PubMed}

Mesh Term: "adenoids", "adenoidectomy", "reoperation"

Full Term: revision, re-growth, epidemiology

(("Adenoids"[Mesh]) OR ("Adenoidectomy"[Mesh])) AND ("Reoperation"[Mesh] OR "revision" OR "regrowth" OR ("epidemiology"[Mesh])) Filter by humans, child: birth-18 years, infant: birth-23 months

$\Rightarrow 723$

\section{Medline}

Mesh Term: "adenoids", "adenoidectomy", "reoperation", "epidemiology"

Full Term: revision, re-growth

((exp "adenoids") OR (exp "adenoidectomy")) AND ((exp "reoperation") OR ("revision".mp.) OR ("regrowth".mp.) OR (exp "epidemiology")) Filter by humans, all child: 0-18 years

$\Rightarrow 199$

\section{EMBASE}

Mesh Term: "adenoids", "adenoidectomy", "reoperation", "epidemiology"

Full Term: revision, re-growth

Filter by humans, newborn: up to 1 month, infant: 1 to 12 months, child: 1 to 12 years or unspecified, preschool child: 1 to 6 years, school child:

7-12 years, adolescent: 13 to 17 years

(('adenoids'/exp OR adenoids) OR ('adenoidectomy'/exp OR adenoidectomy)) AND (('reoperation'/exp OR reoperation) OR ('revision'/exp OR revision) OR ('epidemiology'/exp OR epidemiology) OR ('regrowth'/exp OR regrowth))

$\Rightarrow 991$

\section{Cochrane library}

Mesh Term: "adenoids", "adenoidectomy", "reoperation", "epidemiology"

Full Term: revision, re-growth

(("Adenoids"[Mesh]) OR ("Adenoidectomy"[Mesh])) AND ("Reoperation"[Mesh] OR "revision" OR "regrowth" OR ("epidemiology"[Mesh])) $\Rightarrow 15$

Total $1928 \Rightarrow$ After removing duplicates $\Rightarrow$ Total 1405; Searching date: 2018/2/25 
Supplement Table 2. Risk of bias analysis for included study.

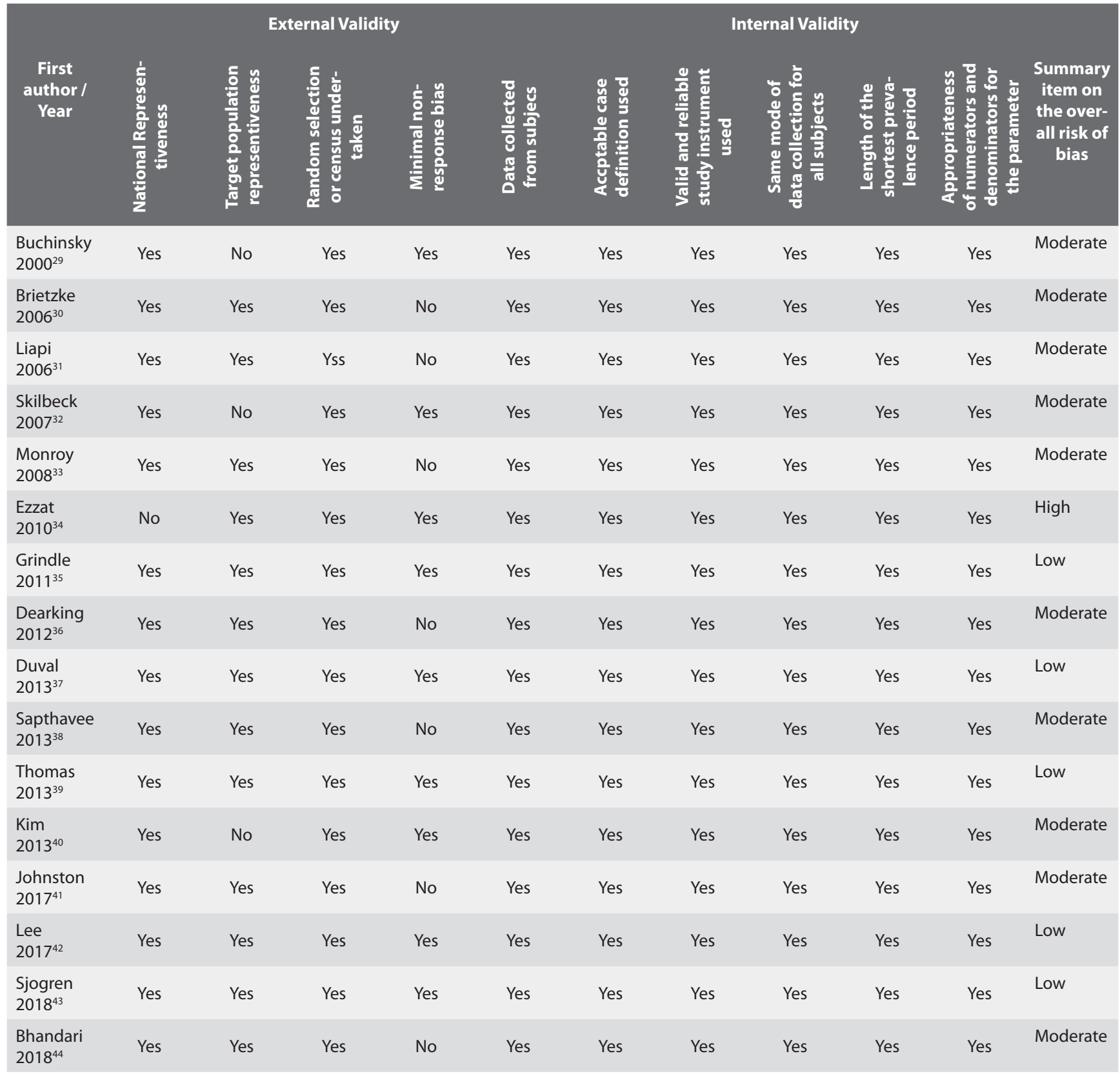

